TROJAN, Vaclav

\title{
THE ISSUES OF PROFESSIONAL PREPARATION OF SCHOOL HEADMASTERS IN THE CZECH REPUBLIC
}

\section{Introduction}

The headmaster is a crucial and irreplaceable person of each school. (Translator's note: For the sake of clearness, "he" will be used when "headmaster" is replaced by a pronoun in the text below, but it will mean both genders.) The role of that person is still undervalued not only in the current process of curricular reform, but primarily in everyday life of the school; the consequences of his decision making often affect many people for a long time. Not only Czech, but also international references put stress on professional preparation (Schratz, 2010), on his education and cultivation of competences (Lhotková, Trojan, \& Kitzberger, 2012). But the preparation is not further specified.

In the present situation, the position of school headmaster is assumed by a fully qualified teacher with prescribed duration of teaching experience. Studies start revealing that the headmaster is not merely a specific case of a teacher, but that it is a peculiar, specific position, irreplaceable for the school and requiring exceptional and comprehensive preparation. It turns out that a lot of headmasters equipped only with teaching qualification and experience fail in their function or manage the challenging job only with great difficulties. Therefore the article will deal with the issues of their professional preparation.

If perceiving the teacher as a key actor of transformation of the school, the headmaster plays a completely crucial role in that process. It is therefore necessary to analyze also the concept of the headmaster profession in new conditions and to seek innovated approaches to their education and lifelong professional development. The branch of School Management (Everard \& Morris, 1996) researches different aspects of management of school in changing conditions (Trunda, 2012) and, as such, it must reflect the development, the current status and the trends of the branch, as well as the trends of the development (Covey, 1991) of the society and of the educational system of neighbouring countries. Of course, the headmaster as the fundamental agent (Pisoňová, 2008) and crucial factor of the development of the school constitutes one of the primary spheres of interest, as well as the holistic development of that irreplaceable person.

A considerable part of foreign references from the area of pedagogical leadership works on the assumption that the school has the main and unique task: teaching and learning of all pupils (Bush, Bell, \& Middlewood, 2010). According to foreign studies, school management is the second most important factor influencing the pupils' learning; the first factor consists in the form of teaching (Leithwood, Day, Sammons, Harris, \& Hopkins, 2006). 


\section{Points of departure}

$>$ The school headmaster has been paid low level of systematic scientific attention and care so far

$>$ There is a number of partial studies; however, they are not linked by any unifying idea and methodology

$>$ The concept of the headmaster position undergoes a dynamic development both in the Czech Republic and abroad

$>$ Expert reports repeatedly point out the drawbacks of headmasters in the area of management of teaching quality

$>$ The system of headmaster education evidently gets obsolete, and so the professionalization of the headmasters lags behind the professionalization of the teachers

$>$ No career model of the teacher and of the headmaster has not been created and adopted so far

When comparing the situations in individual OECD countries, the Czech school has one of the highest values of autonomy both from the curricular and from the economic perspective (Trojan, 2011). The headmaster is burdened with fulfilling tasks from many areas (law, economics, school operation), and therefore has demonstrably less and less time for the management of the pedagogical process. The assessment report (McKinsey@Company, 2010) sees one of the key measures for a turn of the negative trends in the Czech education in releasing the headmaster's capacity for the area of the pedagogical issues. The OECD assessment report (Santiago, 2012) has the same result. The school headmaster is overloaded by lots of formal work and devotes approximately a fifth of his worktime to the educational process and to the management of the school quality (Trojanová, 2014). The administrative burden, constituting probably not only a Czech phenomenon, detracts the headmaster not only from the management of the pedagogical work of the school but also from the contact with the development of teaching theory and practice. That creates the risk of obsolescence of the headmaster's pedagogical expertness, resulting in his not being able to act as a pedagogical leader any more (Dvořák, 2011).

The headmaster's job has been experiencing essential changes in the course of recent years. When comparing the structure of the headmaster's work and the level of his responsibility twenty years ago and at present, we can state that we are facing two different professions. The traditional conflict of his profession is based on the tripersonality of the concept of roles. The theoretically described and accepted roles of leader, manager and executor of process (Lhotková et al., 2012) mean that the headmaster carries out all above stated roles and often switches from one role to another in the course of one day. Particularly in the area of management of pedagogical process and factual subordination to the leader of the subject team at the time of direct teaching duty, such systematic ambiguousness brings about difficult managerial situations. The headmaster must be comprehensively educated (with stress on andragogical principles and branch overlaps); he must be an expert on the 
management of school and on the management of teaching quality, with ability to reflect external influences affecting the educational system (Liesman, 2011).

\section{Theoretical aspects of the issue}

The topic of the teacher, his socio-professional roles, the key professional competences, the creative character of his activities, the professional autonomy, the attitude-ethical qualities and other issues constitute one of the shaping topics of the Czech and international pedagogical research. (OECD 1994; Spilková, Vašutová 2002; Vašutová 2004; Walterová 2004; EK 2007; Spilková, Vašutová 2008) The common starting point of the increased interest in the above stated areas consists in the fact that the increasing importance of education in the society is closely related to the issue of quality of the teachers and of their professionalization. The teachers are considered key players in the field of educational reforms and innovations. At the same time, it is pointed out that in the context of the changing Czech society and the education system, the demands on the teaching profession are essentially shifting. (Spilková, Vašutová 2008)

The teacher is the central and starting concept in the comprehensive reflections about the teaching profession. But it is often used at a generalized level, abstracting from the variability of many aspects of the professional activities, qualities, working conditions and variable working contexts. In spite of how frequently the concept of teacher is dealt with, "it is almost never precisely defined, as if it is automatically considered unambiguous to everybody (Prücha, 2010)." Yet the simple, but legitimate question "who is the teacher?" starts getting problematic as soon as we start reflecting on it for professional and scientific purposes. This is a key moment, as it is not divested of problems to view the headmaster through a prism of the category of teacher: at least, he is not a typical representative of the teaching profession, primarily with regard to direct teaching activities and to the character or structure of the work he carries out apart from the actual teaching. On the other side, however, there is probably no doubt that the headmaster does not deviate from the definition of the teacher, as long as he teaches pupils at least during a part of his working time (e.g., according to the OECD indicators, only the headmasters with zero teaching workload are not included among teachers ${ }^{1}$ ).

Two type-different working activities of two different professional directions overlap in the headmaster's profession. First, it is upbringing and education (the headmaster must meet the qualification preconditions of a teacher and fulfil the standard of teacher's professional qualities in his work); second, it is management, including fitness for general management and coordination of the school and assumption of responsibility for creation of development strategies of the school. We believe that the core activities of headmasters consist in the latter area. The activities of the headmaster as executor of direct pedagogical duties, i.e. teaching, is marginal with regard to the essence of his role in the school. But the present occupational and qualification specification anchors the school headmasters in two

\footnotetext{
${ }^{1}$ Education at a Glance: OECD Indicators, 2001, s. 309-400.
} 
professions at the same time. It results from the traditional perception of the headmaster's position primarily as a teacher who is "the one and the first of the teaching staff", reflecting the habitual idea that "the person heading the school is primarily a teacher. (Dvoŕák, 2011)". However, not only abroad but also in our country, the transformation of the state administration (dissolution of branch management, new legal subjectivity of schools, curricular autonomy of schools, etc.) produced an essential change of the job contents and extension of the administration and operation paperwork the headmaster has to take care off, additionally to the management of the pedagogical process and implementation of the actual teaching (compare Novotný 2005; Prášilová 2008; Sedláček 2008). Thus the character of the headmaster's work has been transformed from the "heading teacher“ (Dvoŕák, 2011), or from the "pedagogical school leader to a comprehensive manager" (Pol, Úvodní fáze profesní dráhy ředitelů základních škol, 14,1).

The starting point for formulation of scientific knowledge foundations on the headmasters, if they are to be included in the teaching profession, consists in the research of professional roles and professional competences needed for good mastering of the tasks of the leading pedagogical worker in dynamically changing conditions, in sufficient knowledge of the conditions and trends in the development of the society and of the educational system, as well as in thorough familiarity with the specific working situation of the headmasters and with the development of their professional career.

The guiding topic of the reflections on the teaching profession concerns the teachers' quality and responsibility for the quality of teaching, which are getting more and more relevant with the growing importance of education in the knowledge society. In that context, recent decades have brought numerous research or development projects dedicated to the teachers' quality, ascertainment of their professional performance, identification of the teacher's key professional competences and formulations of the professional standard as a tool for education, professional development and assessment of the teachers. Many studies have shown that the teachers' quality is the most important factor influencing the quality of school education and the pupils' results (Darling-Hammond 2000; Hanusek, Kain, Rivkin 2005).

At the same time, a lot of studies (Leithwood 2001, 2006; Mulford 2003; Waters at al. 2003; Robinson et al. 2009; Abari-lbolya, Baráth 2010) argue that the method or level of leadership of the school also rank among the most important factors influencing the pupils' learning and thus the general quality and efficiency of the school or of the education, respectively. Therefore, when the headmasters are concerned, we believe that it is more essential to concentrate on the second area of their activities, i.e. to focus the research on their managerial and leadership competences. Thus if our discussions on the teaching professions are aimed at expressing the substance of the teacher's professionalism, roles and competences, then the preparation of headmasters and mediation of the competences needed for high-quality practice of their professional share constitute a similarly important area of the discussion. 
If, within the broad spectrum of the headmaster's professional activities, we focus only on the care area, derived from the primary purpose of the school, i.e. on the area of education, or more exactly influencing of the educational results of the pupils, we can find inspiration for example in the New Zealand document (Robinson 2007), which is a meta-analysis of 26 international studies (18 of them made in the USA) showing evident correlation between the school leadership and the pupils' results. A different approach to the organization of the knowledge of how leadership influences the pupils' learning was offered by Leithwood, Louis, Anderson and Wahlstrom (2004) who enumerated three main areas: demarcation of direction (creation of a vision, specification of goals and priorities, postulation of high performance demands), development of people (individualized support and own example) and redesigning of organization in the spirit of development of cooperation and participation in decision making.

Some discontinuity can be observed in the Czech Republic, as for addressing of the issues of competences of the managers in the educational system. Their legislative competences, i.e. competences given by legal regulations, are clearly delimited, but a statement of the competence profile with regard to the specification of knowledge and skills is missing. Sporadic studies in our country (Nezvalová 2003; Rýdl 2007; Trojan 2012) do not represent the necessary comprehensive solution of the issue.

We can observe different levels of the autonomous headmaster's position across the systems of education of different countries. International comparative analyses (EURIDICE 2007, 2012, TALIS 2008, PISA 2011) have been traditionally assessing the autonomy of schools from two perspectives: management of resources (both financial and human) and management of educational matters (management of the curriculum). The extensive research of the PISA 2009 study constructed two types of indexes for the needs of statistical evaluation: the index of school responsibility for allocation of resources and the index of school responsibility for the curriculum and for the assessment (the average of both indexes equals zero; thus the indexes express standard deviation from the average of OECD countries). For example the relatively highest degree of school autonomy, as expressed by the index of responsibility for the curriculum and for the assessment, can be found in Japan, Holland, the Czech Republic, Great Britain and New Zealand. The school headmasters from the above stated countries stated to have a high level of freedom in independent decision making in the following four areas: $1 /$ Determination of rules for the assessment of pupils; 2 / Selection of the textbooks for the pupils to learn from; 3 / Determination of the educational contents of individual subjects; 4/ Decision making on the subjects to be offered by the school. The countries with the lowest level of the index include Greece, Turkey, Jordan and Tunisia. It is therefore evident that the OECD data reveal a broad dispersion of the level of school autonomy in individual countries.

That fact leads to the conclusion that reaching an international consensus in standardization of the headmaster profession is actually excluded. The OECD data show unambiguously that 
it is not quite possible to compare the professional performance of the headmaster of a Greek and Czech school, as their characteristics are situated at the opposite poles of the spectrum, and thus the conditions of and demands on the necessary competences are not commensurable. But such postulate applies also to research projects aimed at standardization of the headmaster profession based on the adoption of foreign experience. If we are to base our further research of the issues of the standard of headmasters on comparative analyses, we must follow the system of educations by related characteristics (e.g. as expressed by both autonomy indexes according to the PISA study). In case of the Czech Republic, the demand is met by the Netherlands and Great Britain. Both countries have experience with the development of standards for headmasters, as stated above.

The above stated lists show that the common tools for evaluation of headmaster competences include catalogues of attributes of such professional performances, leadership methods, etc. that are (based on different analytic studies and research findings) identified as functional, efficient, good practice examples. But on the other hand, it is evident that quality in this context is and cannot be a static value that could be achieved once and away, particularly with respect to the constantly changing conditions in education. It is rather a lifelong path of a professional. For that reason, we consider it important to pay attention also to the dynamic components of the headmaster profession. In the process of creation of the professional standard for pedagogical managers, we consider it very important not to underestimate the job analysis of a school headmaster and to gather a sufficiently robust knowledge database on this profession subgroup, as the school headmasters will have to cope with the demands and expectations set by the professional standard. As we perceive a great potential tension "on the edge" of two standards (teacher's competences and manager's competences), we are also interested in a broader internal and external context of the school, as it determines fundamentally the conditions in which the headmaster will strive to meet the standard and which determine the professional success. The thing is that a good and competent teacher cannot be expected to be automatically a good headmaster. Nevertheless, some studies show that the prestige the headmaster has built in the course of his preceding teacher's career constitutes an important factor of his adaptation to the position of headmaster.

At present, it is unimaginable for the headmaster to practise his job well only based on intuitive processes, in spite of a great talent for the related activities. Even in case of a very massive and high-quality delegation, such job cannot be practised well without a knowledge background. Therefore the need of the demand on the study of school management even before starting to practice the headmaster job becomes more and more accentuated. The career system under preparation should consider that need; only applicants with completed education in the above stated area should be allowed to register in the competition proceedings. At the same time, similarly as with respect to teachers, a concept of compulsory further education of headmasters who are already practising their jobs should be elaborated within the system. 


\section{Education of headmasters}

At present, the demands on the practice of the headmaster position in the Czech Republic are considerably obsolete already and do not correspond to the dynamic development; that applies also to the progress of further headmaster education. A starting headmaster must have the prescribed pedagogical education and teaching experience, specified by the type of school at 3-5 years, but no "headmaster" education before entering the position has been specified yet. it is therefore quite probable that we often have schools managed by teachers who are honest and pedagogically educated, but laymen who will try to manage the school by trial-and-error method at the beginning. The situation is dismal, without exaggeration. I will summarize the greatest problems resulting from the missing headmaster career-system:

- The starting headmaster is not thoroughly and holistically prepared for the practice of his job

- Any degrees of the headmaster career are not distinctively marked; the headmaster has no obligation of further development in the area of school management or employee leadership

- The school headmasters do not have any systematic support

- Uncertain position of the headmaster, resulting from strong politicization of the educational system. Particularly in small villages, the schools are managed by laymen; the assessment of the headmasters performed by the school authorities is random and disorganized (Kuchař, 2013).

- Expert headmasters are not systematically used for example as mentors, educators or assessors. The great number of school authorities and the reduced opportunities of the state in this area lead to a relatively probable departure of the headmaster after the termination of his term of office; the headmaster is endangered from labour-law perspective, as compared to other teachers

- The existing, often very sophisticated educational programs for pedagogical managers do not constitute a comprehensive system (at present, the following programs are available: Studies for school headmasters, Studies for pedagogical managers, School management (Bachelor discipline) and Education management (subsequent Master discipline))

- The present condition of completing the compulsory educational program within two years after entering the position burdens the headmaster in the most sensitive and challenging period in which he must, additionally to the development of his own school, pursue the fulfilment of the conditions of the educational program

- The compulsory educational program (Studies for school headmasters) is not sufficient for the practice of the headmaster job both with respect to its prescribed duration of 100 hours and to its contents, as it does not cover for 
example the area of people leadership. The other above stated educational programs have been facultative so far.

- The educational programs often do not consider the diversity of the audience with respect to the duration of the headmaster experience and the resulting educational needs

According to the valid regulations, ${ }^{2}$ the applicant for headmaster position must have pedagogical education and the prescribed teaching experience; but no regulation speaks about prescribed education from the school management area. Ironically, the obligation is set for the most challenging stage of starting the job, when the new headmaster must attain the prescribed education within two years from starting the position. Unfortunately, the prescribed level is relatively low; the educational program takes 100 hours and its standard does not include the area of people leadership at all. Other educational programs are implemented in the Czech Republic as well, for example within lifelong education called Studies for pedagogical managers, 350 hours, and the Bachelor studies of the School management discipline, implemented in combined form of studies, three years of basic duration. Both programs can replace the above stated managerial foundations. In recent five years, the subsequent Master discipline called Education Management has been taught in combined form in only one centre in the Czech Republic (School Management Centre of the Faculty of Education of Charles University in Prague); at present, it offers the highest education to a broad spectrum of managers from schools, offices, inspection, the Ministry of Education and, last but not least, it is intended also for school authorities.

The system of education is considerably affected also by the fact that so far, there has not been any career model to structure the headmaster education, distinguish the particularities of the individual career states and to force the headmasters to implement professional development. It is also worth considering that perhaps a specified level of managerial qualification or a demonstrable experience in the position of deputy headmaster or a crucial position with decision-making authorities at medium-management level should be set as legal condition to submit an application for the headmaster position.

The headmaster is responsible for all areas of life of the school and, at the same time, acts as a teacher. That particularity, that peculiarity of the headmaster's work that, so to say, complicates the school management, is often overlooked (Pisoňová, 2012). It has been unimaginable in the Czech educational context that a school headmaster has no teaching education, no teaching experience, and does not act as a teacher parallelly to the practice of his function (Trojan, 2012); the amount of direct teaching work depends on the number of classes of the relevant school. At the same time, the headmaster is expected to be an equally good economist, clerk, HR officer or law expert.

\footnotetext{
${ }^{2}$ Act 561/2004 Coll. on preschool, elementary, secondary, higher professional and other education (School Act) and Act 563/2004 Coll. on pedagogical employees, as amended
} 
There is no obligation of preceding education in the school management area specified for the headmaster. The new school manager is under a huge strain and it may have fatal impact when combined with the obligation of starting to study immediately. The truth is that in the neighbouring countries, it is rather unusual for the headmasters to have such obligation (Pol, Norská zkušenost, 2010); but on the other hand, experts point out the advantage of knowing the relevant issues in advance, as such knowledge contributes to influence the decision-making process of the future headmaster. It is certainly better if a person not confident of his capabilities to practice the job of headmaster changes his mind before rather than after starting the job.

School regulations in general set the obligation of further education to pedagogical employees. The obligation is set in quite a vague manner; it is within the headmaster's competence, but on the other hand, paid leave for so called self-study is linked to it; pedagogical employees have 12 days of such unpaid leave per school year in the Czech Republic, including the headmaster, who is also a pedagogical employee. But the headmaster does not have the obligation of further managerial education. It has been pointed out already that the statutory education level for headmasters is low and that it cannot suit and suffice to the headmaster for the whole duration of practice of his job.

The system does not make use of experienced headmasters who could be purposefully used as initiating headmasters, mentors, coaches or educators of other headmasters. It does not mean that many educators do not cooperate with such experienced people; but the article points out systematic drawbacks. It is to be hoped that the future career model will eliminate that obstacle too.

The current educational programs are always implemented as a whole; only sporadically, there is a selective module system where the participants choose individual partial study modules due to changed situation, in order to get new information and to strengthen their competences, not due to a prescribed obligation.

The traditional areas of headmaster education - legal regulations and economics - are not accentuated as primary any more. Their importance is still pointed out, but people leadership and pedagogical process management is getting into focus. The latter area is certainly related with the estimated headmaster's responsibility for the education results of pupils in statewide comparisons.

New areas of the headmaster's responsibility are revealed - the above stated responsibility for the pupils' results, as well as the increasing importance of education of pedagogical employees. The new role of the headmaster as educator of the teachers is delimited. First and foremost, as direct educator, i.e. the role of the headmaster as instructor; the headmasters must be helped in that area. It is necessary to strive not only for strengthening of the headmasters' role and for creating their career model, but also for integrating the necessary activities into the educational programs for managers. The reflection of needs and 
the analyses of the situation show that the headmaster is the crucial factor of the development of a successful school, and as such, he must be fitted with adequate skills for the practice of educational activities as well as with the corresponding andragogical and generally pedagogical knowledge.

\section{Potential future situation}

In recent two years, the framework of the career system of the teacher has been prepared within a national project, including the career development of headmasters.

The proposed model will certainly create clearly defined career degrees. I am convinced that they will not only help to set more clearly the potential development and to get better grasp of individual career stages, but that they will also, in a manner, make the headmaster profession more attractive, calm down the turbulent and uncertain headmaster field and result in creating preconditions for increasing level of the quality of education in the Czech Republic.

The existing development of the career system shows that the headmaster career will directly follow up with the teacher career; it will probably constitute the 3rd degree of the career system of the teacher that will be indispensable to assume the headmaster position. According to that system, the teacher performs work in a high quality exceeding the common standard. The teacher is perceived as an expert in his branch. He continuously develops in his subjects, branch didactics, pedagogy, psychology, special pedagogy and in the field of class management. He achieves demonstrably excellent results in his work, he is positively evaluated by the school management, by the pupils and by their parents. He is a respected advisor and helper to his colleagues at school, passing them his experience. In that way, he contributes actively to the growth of quality within his school. His work for the school is very difficultly replaceable, thanks to his qualities. He is the pedagogical leader of the school.

In compliance with the tradition and the existing development, we are not able to imagine that the school headmaster should not have teaching experience and direct teaching obligation. Although there are some opinions preferring the managerial perspective (particularly in secondary education, such arguments sound logical; the schools are often big and the possibility of a headmaster coming from company practice suggests itself), similar considerations are not relevant today, and they certainly will not be relevant for a long time.

The first degree will cover the period before the competition, so it will be the preparatory period. The future headmaster will have to pass compulsory education as precondition of the competition proceedings. The education offered by educational institutions will have to be extended, so that the future headmaster can complete the prescribed educational program out of his working hours; the program will probably have limited validity, e.g. 3-5 
years. It should be completed out of the actual teaching hours, last but not least in order to eliminate the barriers created by the existing headmasters fearing future headmaster competitors.

The second degree will constitute theadaptation period; the duration of that degree will probably be approved at two complete school years. In that stage, the headmaster will start preparing thoroughly his own portfolio to document his professional development. As he has passed the compulsory education in the preceding degree, he will not be burdened by the obligation to pass another educational program during the first two years of work. An important component, particularly in that stage, will consist in the support from the introducing headmaster; this aspect is fatally missing at present. According to the existing proposals, the adaptation period will be completed by the headmaster by an interview before a commission that will assess the submitted portfolio and the headmaster's general professional progress. The introducing headmaster will act as the crucial person whose voice will be substantial for the approval of the advancement to a higher career degree. It has not been discussed yet what steps will be taken in case the conditions are not met; the opportunity of one retake of the interview is expected. The completion of the second degree will constitute a crucial moment of the headmaster career; it will be finished by the decision whether the respective employee is able to practise the school headmaster activities.

The third degree can be called the stage of professional certitude. The headmaster has demonstrated his ability to manage the school already, he has defended his competences before the commission and he is entering the deeper layers of practice of headmaster work. Most headmasters will remain in that degree. Of course, the headmaster will be able to decide at any time to improve his competences in the context of one school or to prepare for the highest career degree in which he could influence other headmasters or intervene in the system of their preparation and education.

Relatively few headmasters will decide to enter the highest degree. Not only due to the fact that it will be conditioned by high quality of the managerial work but also by educational demands that can be currently compared for example with the Master discipline of Education Management. Such headmasters will develop the whole career system, acting as mentors, introducing headmasters, members of commissions or educators of other headmasters. Therefore that degree can be called the stage of new challenges.

A sensitive point will consist in the crossovers, the advancements between the individual degrees and the persons assessing the headmaster competences. I can feel the least problem between the first and the second degree; that advancement will be decided by the competitive commission. The subsequent crossovers will have a more complicated situation and their implementation will need a clear but sensitive communication. I add one of the partial conclusions of the survey carried out among the students of the School Management discipline in January 2014 for completeness. The total number of 175 respondents included $53,7 \%$ active headmasters. One of the questions was focused on the composition of the 
commission assessing the headmasters' crossover between the individual degrees. The question: "Who should not be a member of the commission that will decide about the headmaster's advancement between the individual degrees?" was answered by the respondents as follows:

They would mind most a representative of major pupils $(86,7 \%)$ and a representative of parents $(71,4 \%)$; on the contrary, they would mind least an expert on education of managers $(5,4 \%)$ and a representative of the school authority $(15,2 \%)$. The cause of the high percentage of negative answers to the involvement of parents and major pupils cannot be unambiguously interpreted, but the existing negative experience of the employees with boards of education will certainly play its role. It is evident that the concept of parents as customers of the school is still limping along.

\section{Conclusion}

The postponements of this serious issue are caused particularly by the frequent changes at the Ministry of Education. As long as the school headmaster is not paid essential attention, as long as a system of lifelong development from the preparation for the assumption of the position to the use of expert headmasters is not created, the basic conditions for the development of schools and improvement of the results of each pupil will not be established.

The article dealt with the relevant topic of education of school headmasters in the Czech Republic. It is indisputable that the headmaster is an essential factor influencing the quality of the school, the development of the pupils and of their results. Therefore highest attention should be paid not only to the preparation of the headmasters but also to their lifelong development and indispensable support. The text pointed out the existing problems, described the current situation and suggested a direction of potential further development.

\section{References}

- Abari-Ibolya, E., \& Baráth, T. (Eds.). (2010). Improving School Leadership in Central Europe. Budapest: Tempus Public Foundation.

- Bush, T., Bell, L., \& Middlewood, D. (2010). The principles of educational leadership\&management. London: Sage.

- Covey, S. (1991). Principle-centered Leadership. New York: Free Press.

- Darling-Hammond, L. (2000). Teacher quality and student achievement: A review of state policy evidence. Educational Policy Analysis Archives, 8(1). Dostupné z http://epaa.asu.edu/ojs/article/download/392/515

- Dvořák, D. (XII 2011). Pedagogické vedení školy: hledání zdrojů a obsahu pojmu. Orbis scholae, stránky 9-25.

- EK. (2007). Improving the Quality of Teachers.

- Everard, K. B., \& Morris, G. (1996). Effective School Management. London. 
- Hanusek, S., Kain, E., \& Rivkin, J. (2005). Teachers, Schools, and Academic Achievement. Econometrica, 73(2), 417-458.

- Kuchař, F. (2013). Každý jsme jiný, přesto musíme společně řídit školství. Řizení školy, 5., Prague: Wolters Kluwer ČR, a.s.

- Leithwood, K. (2001). School leadership in the context of accountability policies. International Journal of Leadership in Education, 4(3), 217-35.

- Leithwood, K., Day, Ch., Sammons, P., Harris, A., \& Hopkins, D. (2006). Succesfull school leadership: What it is and how it influences pupil learning. Nottingham: University of Nottingham.

- Leithwood, K., Day, C., Sammons, P., Harris, A., \& Hopkins, D. (2006). Seven strong claims about successful school leadership. Nottingham: National College for School Leadership.

- Lhotková, I., Trojan, V., \& Kitzberger, J. (2012). Kompetence řídících pracovníků ve školství. Prague: Wolters Kluwer ČR, a.s.

- Liesman, K. (2011). Teorie nevzdělanosti: omyly společnosti vědění (XXI. století. vyd.). (J. Zoubková, Překl.) Prague: Academia.

- McKinsey@Company. (2010). Klesající výsledky českého školství. Prague.

- Mulford, B. (2003). School leaders: Changing roles and impact on teacher and school effectiveness. Dostupné z http://www.oecd.org/edu/school/2635399.pdf

- Nezvalová, D. (2003). Kompetence ředitele školy. e-Pedagogium (on-line), 3( 1). Available from the http://epedagog.upol.cz/eped1.2003/clanek02.htm

- Novotný, P. (2005). Ředitelé a řízení kvality ve škole. In Studia Paedagogica, Sborník Filozofické fakulty brněnské univerzity, Brno: Masarykova univerzita, 2005, U10, č. 1, s. 49-66. ISSN 1211-6971.

- OECD. (1994). Quality in teaching. Paris: OECD.

- Pisoňová, M. (2008). Leadership ako súčast' manažérskych funkcií. Prešov: Vydavateĺstvo Michala Vaška.

- Pol, M. $(14,1)$. Úvodní fáze profesní dráhy ředitelů základních škol. Studia paedagogica, stránky 109-126.

- Pol, M. (2010). Norská zkušenost. Brno: MU

- Prášilová, M. (2008). Řízení základní školy v letech 1990-2007. Olomouc: UP.

- Průcha, J. (2010). Pedagogická encyklopedie. Prague: Portál

- Robinson, V. (2009). School Leadership and Student Outcomes: Identifying What Works and Why. New Zeland: The University of Auckland.

- Rýdl, K. (2007) Jak hodnotit ředitele. In Učitelské noviny, č. 11, str. 5-8. Prague

- Santiago, P. (2012). Zprávy OECD o hodnocení vzdělávání. Česká republika. Prague

- Sedláček, M. (2008). Řízení základní školy. Perspektiva prípadových studií práce reditelů (Disertační práce). Brno: MU.

- Schratz, M. a. (2010). Zlepšování kvality škol ve střední Evropě. Prague: MŠMT ČR.

- Spilková V., \& Vašutová J. (Eds.). (2002). Rozvoj národní vzdělanosti a vzdělávání učitelů v evropském kontextu. Prague: UK PedF.

- Spilková, V., Vašutová, J. at al. (2008). Učitelská profese v měnících se požadavcích na vzdělávání. Výzkumný záměr. Úvodní teoreticko-metodologické studie. Prague: UK PedF.

- Trojan, V. (2011). Vzdělávání rídících pracovníků v českém školství. Orbis scholae, 3(1), stránky 107-122. 
- Trojanová, I. (2014). Ředitel školy a střední management. Prague: Portál.

- Trunda, J. (2012). Řízení školy ve znalostní společnosti. Prague: PedF UK.

- Vašutová, J. (2004). Profese učitele v českém vzdělávacím kontextu. Brno: Paido.

- Walterová, E. (2004). Úloha školy v rozvoji vzdělanosti. Prague: Paido.

- Waters, T., Marzano, R. J., \& McNulty, B. (2003). Balanced leadership: What 30 years of research tells us about the effect of leadership on student achievement. Available from the http://www.ctc.ca.gov/educatorprep/ASC/5031RR_BalancedLeadership.pdf 